\title{
POTENSI WISATA GASTRONOMI HALAL DI WILAYAH PECINAN, PETAK 9, GLODOK JAKARTA
}

\author{
Shanti Pujilestari ${ }^{1}$, Julfi Restu Amelia' ${ }^{2}$, Muhammad Fajri Romadhan ${ }^{3}$ \\ Fakultas Teknologi Pangan dan Kesehatan, Universitas Sahid Jakarta \\ Jl. Prof. Dr. Supomo No 84, Tebet, Jakarta Selatan 12870 \\ Email Korespondensi: shanti_pujilestari@usahid.ac.id
}

\begin{abstract}
ABSTRAK
Tujuan penelitian ini adalah untuk : (1) Mengidentifikasi restoran tempo dulu yang menjadi favorit dan diasumsikan halal; (2) Mengetahui perilaku halal dari sisi pemilik restoran, termasuk kesediaan mengikuti sertifikasi halal; dan (3) Mengetahui pendapat pakar mengenai perkembangan wisata halal khususnya pada wilayah pecinan. Metode yang digunakan adalah survey, sedangkan penelitian ini adalah penelitian deskriptif dengan data kualitatif. Wawancara dilakukan kepada pemilik restoran, sedangkan wawancara mendalam dilakukan kepada pakar wisata halal Kementrian Pariwisata RI. Hasil penelitian menunjukkan bahwa : (1) Restoran tempo dulu yang menjadi favorit dan diasumsikan halal sebanyak 6 buah; (2) 43,3\% perilaku halal pemilik restoran rendah, tetapi $83,3 \%$ bersedia mendapat pendampingan sertifikasi halal; dan (3) Pakar menyatakan bahwa pentingnya informasi halal bersertifikasi MUI pada restoran di wilayah Pecinan Petak 9, Glodok, Jakarta.
\end{abstract}

Kata kunci : Gastronomi, muslim, halal, restoran dan Tionghoa

\begin{abstract}
The objectives of this study are to: (1) identify past restaurants that are favorites and are assumed to be halal; (2) Knowing the halal behavior of the restaurant owner, including the willingness to follow halal certification; and (3) Knowing the opinion of experts regarding the development of halal tourism, especially in the Chinatown area. The method used was a survey, while this research was a descriptive study with qualitative data. Interviews were conducted with restaurant owners, while in-depth interviews were conducted with halal tourism experts from the Indonesian Ministry of Tourism. The results showed that: (1) There were 6 restaurants in the past that were favorite and assumed to be halal; (2) $43.3 \%$ of the halal behavior of restaurant owners is low, but $83.3 \%$ are willing to receive halal certification assistance; and (3) The expert stated that the importance of halal information with MUI certification in restaurants in the Chinatown Petak 9, Glodok, Jakarta.
\end{abstract}

Keywords: Gastronomy, Muslim, halal, restaurant and Chinese 


\section{PENDAHULUAN}

Pecinan Petak 9 adalah wilayah yang memiliki beberapa restoran dengan nuansa tempo dulu. Makanan dan minuman yang lezat mengakibatkan wisatawan datang kembali ke kawasan ini. Disamping itu, terdapat wisatawan yang datang kembali dengan tujuan ingin menikmati lagi makan dan minum yang disajikan dengan resep turun temurun serta menikmati suasana makan tempo dulu.

Kawasan Glodok merupakan pusat perdagangan etnis Tionghoa di Jakarta sejak dahulu yang didominasi salah satunya oleh kuliner. Orang yang melakukan kegiatan bisnis maupun berbelanja di wilayah tersebut membutuhkan makan, sehingga berdirilah pusat jajanan yang sampai sekarang masih bertahan, yang disebut dengan petak 9 . Makanan Tionghoa banyak yang berbahan baku tidak halal sehingga tidak boleh dikonsumsi oleh wisatawan muslim. Budaya Tionghoa sangat lekat pada wilayah ini, diantaranya juga ditunjukkan dengan adanya bangunan gereja, vihara dan klenteng yang dibangun sejak 1650. Tempat-tempat ibadah tersebut kemudian juga menjadi pusat budaya. Budaya Tionghoa semakin kuat diantaranya disebabkan karena sebagian besar pemilik restoran beretnis Tionghoa.

Adanya pasar di sekitar pusat jajanan yang menjual bahan-bahan makanan untuk memenuhi kebutuhan konsumen maupun restoran, dengan susunan yang cukup rapih dan adanya toko Tionghoa tempo dulu yang menjual keperluan sembahyang serta gerabah peralatan masak tempo dulu. Bahan makanan yang dijajakan ada yang tidak biasa, seperti kodok, teripang, sayuran dan buah-buahan segar serta bahan-bahan lain yang memiliki mutu yang baik merupakan atraksi yang menarik bagi wisatawan. Berdasarkan paparan yang telah disebutkan, maka wilayah petak 9 dapat dikatakan sebagai wilayah wisata gastronomi.

Wisata gastronomi di Petak 9 sangat menarik untuk dikunjungi oleh wisatawan yang akan menikmati makanan dengan suasana makan kental budaya Tionghoa, hanya saja kehalalan makanan merupakan masalah yang akan dapat membatasi kunjungan wisatawan muslim. Waskito (2015) menyatakan bahwa sertifikasi halal memengaruhi minat beli konsumen. Artinya pengunjung muslim hanya akan mengkonsumsi makanan dan minuman bila restoran bersertifikat halal MUI. Wisatawan muslim memiliki kewajiban untuk mengkonsumsi makanan halal. Yusof dan Shutto (2012) menyatakan bahwa makanan halal adalah sektor potensial lain yang dapat memengaruhi pariwisata di Jepang. Hal ini karena makanan halal sudah merupakan masalah internasional karena kewaspadaan pengunjung muslim terhadap makanan halal semakin meningkat, padahal target pasar wisatawan muslim cukup besar.

Berdasarkan data Thomson Reuters yang diambil dari 55 negara dalam Global Islamic Economy Report 2014 - 2015 di sektor perjalanan, pada tahun 2013 umat muslim dunia menghabiskan sekitar US\$140 miliar untuk berwisata atau sekitar 7,7 \% dari pengeluaran global. Diperkirakan jumlah tersebut akan meningkat menjadi US\$238 miliar atau $11,6 \%$ pengeluaran global sektor perjalanan di tahun 2019 (di luar perjalanan haji dan umrah). Total pengeluaran muslim dunia pada Tahun 2013 di sektor makanan dan minuman halal mencapai US\$1,292 miliar atau sebesar 10,8\% dari pengeluaran kebutuhan makan dan minum penduduk dunia dan akan mencapai US $\$ 2,537$ miliar atau 21,2\% dari pengeluaran kebutuhan makanan dan minuman global pada 2019. 
Indonesia Travel (2013) dalam Alamsyah (2018) menyatakan bahwa DKI Jakarta adalah salah satu dari 13 (tiga belas) provinsi yang dipersiapkan Indonesia untuk menjadi destinasi wisata halal. Sebagai bagian dari kawasan cagar budaya yang berdampingan dengan wisata Kota Tua di DKI Jakarta, wilayah Pecinan petak 9 Glodok berpotensi sebagai wisata gastronomi halal dan merupakan bagian penting dari DKI Jakarta dilihat dari sisi pedagang maupun pendapat pakar wisata halal.

Berdasarkan paparan yang telah disebutkan, maka penelitian tentang potensi wisata gastronomi halal di wilayah Pecinan Petak 9, Glodok, Jakarta penting untuk dilakukan. Tujuan penelitian ini adalah untuk : (1) Mengidentifikasi restoran tempo dulu yang favorit dengan asumsi halal; (2) Mengetahui perilaku halal dari sisi pedagang; dan (3) Mengetahui pendapat pakar mengenai perkembangan wisata halal khususnya pada wilayah pecinan.Penelitian ini penting sebagai dasar penelitian lainnya untuk mendukung sertifikasi halal MUI pada restoran wisata gastronomi di wilayah pecinan.

\section{METODE PENELITIAN}

Metode penelitian ini adalah survey. Penelitian ini adalah penelitian deskriptif dengan responden dibatasi pada supplier (pemilik restoran) dan pendapat pakar. Wawancara mendalam dilakukan kepada para pedagangdan pakar. Pakar yang dipilih sebanyak 1 (satu) orang yaitu ahli wisata halal dari Kementrian Pariwisata RI.

Penelitian ini dilakukan dengan langkah-langkah sebagai berikut : (1) Menentukan mana saja restoran yang menjadi favorit dan diasumsikan menyediakan makanan halal, (2) Mempelajari karakteristik pemilik restoran yang terpilih dengan menggunakan kuesioner; dan (3) Permohonan kesediaan menjadi responden dan izin untuk melakukan penelitian, baik pada pedagang maupun pakar; dan (4) Pengolahan data penelitian dan penulisan laporan akhir. Data yang dikumpulkan dalam penelitian ini yaitu :

1. Data restoran terpilih dilakukan dengan cara mempelajari blogger bila orang makan di Petak 9 restoran apa saja yang menjadi pilihan (favorit).

2. Restoran yang didapat dari poin 1 , didiskusikan dengan pengelola wilayah mana saja restoran yang diasumsikan halal, pengambilan sampel dilakukan secara purposif.

3. Data karakteristik pemilik restoran yang terpilih, disajikan secara deskriptif meliputi data usia, jenis kelamin, omset per bulan dan agama. Data usia yang diperoleh akan dikelompokkan menjadi tiga menurut BPS, 2016, yaitu 0-14 belum produktif, kelompok penduduk produktif 15-49 tahun, usia produktif 50-64 tahun, kelompok tidak produktif lebih dari 65 tahun. Jenis kelamin dikategorikan menjadi laki-laki dan perempuan; data omset per bulan diberikan secara bebas; sedangkan agama dikategorikan berdasarkan Keputusan Presiden Nomor : 6/2000 yang diperkuat dengan Surat Keputusan Menteri Agama RI Nomor: MA/12/2006 yaitu (1) Agama Islam; (2) Agama Kristen Protestan; (3) Agama Katolik; (4) Agama Hindu; (5) Agama Budha; dan (6) Agama Kong $\mathrm{Hu} \mathrm{Cu}$.

4. Data perilaku halal pemilik restorandiukur denganpertanyaan positif yang menggunakan dua tingkatan skala jawaban, yaitu "ya" dan "tidak". Apabila jawaban "ya" maka diberi skor 1, dan apabila jawaban "tidak" diberi skor 0 . Jumlah pertanyaan yang diberikan untuk mengukur pengetahuan sebanyak 8 (delapan) pertanyaaan, 
sikap 4 (empat) pertanyaan dan perilaku pangan halal pada pedagangsebanyak 6 (enam) pertanyaan,sehingga skor maksimal masing-masing adalah8,4 dan 6 . Pertanyaan dikembangkan oleh auditor halal MUI DKI Jakarta. Untuk menentukan persentase, maka kemudian total skor dibagi dengan skor maksimal tentang pengetahuan, sikap dan praktek pada perilaku pangan halal pedagang dan kemudian dikali $100 \%$. Perilaku pangan halal pada pedagang dikelompokkan kedalam tiga kategori yaitu baik (>80\%), sedang (60\%-80\%) dan kurang $(<60 \%) .3$ katagori ini dilakukan juga oleh Rachmadewi dan Khomsan (2009) serta Murti (2016).

5. Data pemilik restoran yang akan bersedia untuk mengikuti pedampingan sertifikasi halal dibuat dalam persentasi

6. Data tentang perkembangan gastronomi halal dilakukan kepada pakar wisata halal, yaitu tenaga ahli dari Departemen Pariwisata RI. Seluruh pertanyaan yang diajukan terdiri dari pertanyaan positif dan negatif dalam kuesioner.

Analisis data yang dilakukan secara deskriptif sesuasi dengan variabel-variabel yang diamati yaitu 1) Karakteristik responden (usia, jenis kelamin, agama dan jumlah pelayan); 2)Katagori perilaku pangan halal pedagang restoran dan persentase pedagang restoran yang bersedia mengikuti pedampingan sertifikasi halal; 3)Perkembangan wisata gastronomi halal di Pecinan, Petak 9, Glodok.

\section{HASIL DAN PEMBAHASAN}

\section{Restoran Favorit dengan Asumsi Halal}

Restoran favorit diasumsikan menyediakan makanan dan minuman halal adalah: (1) Pantjoran Tea House; (2) Gado-gado Direksi; (3) Kopi Es Ta Kie; (4) Kari Lam ayam atau sapi; (5) Mie Kangkung; dan (6) Laksa Lao Hoe, masing-masing akan dijelaskan sebagai berikut :

\section{Pantjoran Tea House}

Bangunan restoran ini sudah ada sejak tahun 1635 dan merupakan salah satu landmark di wilayah Petak 9. Dalam sejarahnya pada tahun 1928 bangunan restoran sebelumnya adalah toko obat Apotheek Chung Hwa yang disebut tertua kedua di Jakarta. Bangunan direvitalisasi pada tahun 2015, yang kemudian menjadi Restoran Pantjoran Tea House.

Minuman teh yang ada pada Restoran ini adalah teh dengan berbagai rasa yaitu Chinese Tea, Japanese Tea, English Tea dan Indonesia Premium, Jasmine, Oolong, Phu Earl, Smoky Green Tea, Chrysanthemum, Tie Kwan In, Sencha, Genmaicha, Earl Grey, English Breakfast dan Orange Pekoe. Daya tarik minum teh dilakukan dengan konsep kedai teh dengan menyediakan teh dalam teko dan gelas lurik hijau tempo dulu secara gratis di depan restoran. Kedai teh ini dapat diperoleh secara cuma-cuma bagi siapapun.

Daya tarik lain adalah adat penyiapan teh langsung dari pemanasan air dan penyeduhan teh sampai disiapkan di dalam gelas teh yang dilakukan oleh para pramusaji. Penjualan atraksi ini dikemas secara paket untuk 4 orang. Sebagai pelengkap minum teh terdapat camilan ringan, yaitu seafood, daging, sup, sayuran maupun mie. Seperti udang saus hongkong, sup perut ikan, gurame saus telur asin, dan kwetiaw siram seafood. 


\section{Gado-Gado Direksi}

Gado-gado Direksidi Pecinan Glodok termasuk makanan yang legendariskarena mulai berjualan sejak tahun 1967.Gado-gado direksi pada saat ini telah dikelola oleh generasi ke-2. Pada masa perkembangannyabanyak direksi bank di sekitar glodok yang menjadi langganan gado-gado direksi, dari kondisi tersebut maka nama gado-gado tersebut menjadi gado-gado Direksi.

Gado-gado ini tidak seperti gado-gado lain yang dianggap enak dengan menggunakan kacang mede, gado-gado menggunakan kacang tanah yang dibeli di perkebunan rakyat di daerah Tuban.Lontong, aneka sayuran (labu, kol, taoge, kacang panjang, timun, kangkung), krupuk dan emping yang diberi bumbu kacang merupakan campuran bahan dari gado-gado Direksi. Menu lain yang bisa dipesan adalah ayam kampung goreng kremes dan lumpia sayur.

Suasana makan di restoran ini sangat sederhana, tetapi bagi pelanggan yang ingin menikmati suasana makan tempo dulu, maka tidak akan canggung makan di tempat yang sederhanatersebut.Salah satunya gado-gado direksi ini mempertahankan penggunaan gerobak yang berkumpul dengan pedagang gerobak lain dalam satu tempat. Pelanggannya terdapat para pejabat negara dan artis, karena terbatasnya tempat makan maka juga ada pelanggan yang tidak makan di tempat, tetapi dibawa pulang.

\section{Kopi Es Ta Kie}

Warung kopi Es Ta Kie adalah warung kopi yang berada di tengah pasar, tak jauh dari Gang Gloria yang dalam peta resmi DKI bernama Jalan Pintu Besar Jakarta III. Penyebutan Gang Gloria adalah landmark bagi pencinta kuliner terutama kuliner peranakan Tionghoa. Kopi Es Ta Kie sudah melegenda, karena diperkirakan sudah berdiri sejak tahun 1927. Saat ini pengelola warung kopi tersebut merupakan generasi ke tiga dari pemilik pertama.

Pada tahun 1976 generasi ke tiga mencampur beberapa jenis kopi ke dalam satu wadah yang sekarang dikenal menjadi "Es Kopi Tak Kie". Dari namanya memiliki arti, yaitu "Tak Kie" berasal dari kata "Tak" yang artinya orang yang bijaksana, sederhana dan tidak macam-macam. Sementara "Kie" punya arti mudah diingat orang. Suasana tempo dulu yang tergambar jelas didesain interior dan tata ruang yang masih asli bahkan kursi kayu dan meja yang masih dipertahankan. Phylosofi minum kopi langsung di kedai kopi Es Ta Kie adalah kesederhanaan.

Menu kopi adalah kopi hitam atau kopi susu ditambah es atau hangat. Kopi hitam yang diberi es pada saat panas adalah salah satu keunikan minum kopi di kedai ini. Makanan pendamping yang juga disediakan adalah pangsit kuah, pangsit goreng, nasi campur, bakso dan bakcang. Pelanggan yang datang ke kedai kopi ini sebagian besar memang ingin menikmati kopi di kedai sambil menikmati suasana tempo dulu.

\section{Kari Lam}

Kari Lam sudah ada sejak Tahun 1973, yang beralamat di Gang Gloria, Jalan Pancoran, Glodok, Jakarta Barat. Kari Lam pertama kali dibuka di Medan, Sumatera Utara. Nama "Lam" diambil dari sapaan ayah Akiong (pemilik Kari Lam saat ini), Alam, Jadi Kari Lam berarti kari si Alam. Di tempat tersebut disediakan dua jenis menu, yakni kari ayam dan kari sapi, dengan harga per porsi berkisar Rp. 42.000- 47.000. Operasional tempat tersebut sejak pukul 09.00-15.30. Rasa Kari Lam sangat khas karena racikan kuah 
santan khas keluarga Cina-Medan, yang disebut dengan mlekoh. Kari ayam "Kari Lam" berisi ayam yang sudah direbus bersama bumbu kari disuwir dengan menggunakan gunting. Setelah itu, ditambahkan potongan kentang. Aroma kari begitu sedap dengan rasanya karinya sangat gurihMenu tersebut cocok sekali menjadi hidangan makan siang dan dimakan dengan nasi.

\section{Mie Kangkung}

Mie Kangkung bertempat di Gang Gloria, Petak Sembilan, Jakarta. Empat komponen utama dari mie kangkung ini adalah mie, kangkung, suwiran ayam, dan kuah. Suwiran ayam yang diberikan pada makanan ini benar-benar ayam dan bukan potonganpotongan tulang ayam. Rasa kuah yang manis dan kental karena ada tambahan sagu menjadikan mie kangkung ini sangat khas dan istimewa. Mie Kangkung dipatok dengan harga Rp30 ribu per porsi.

\section{Laksa Lao Hoe}

Laksa Lao Hoe berada di Jalan Pancoran 5 Nomor 10 (Gang Kecil setelah A\&W Petak Sembilan). Laksa Lo Hoe ini sudah ada sejak Tahun 1980-an. Lao Hoe dalam bahasa Tionghoa berarti orang tua atau lanjut usia. Laksa Lao Hoe berada di pusat pemukiman orang-orang Tionghoa di Jakarta dan Laksa ini tumbuh serta terjaga di kultur asli dan orisinalitasnya. Keaslian resep diturunkan dari ibu pemilik Laksa Lao Hoe Saat ini (Ibu Ci Linda) yang berasal dari Bogor, maka jika dirunut aslinya Laksa Lao Hoe termasuk dalam rumpun Laksa Bogor. Keluarga Ibu Ci Linda sebelumnya memiliki warung di Cibinong di tahun 1940-1950-an.Laksa yang disajikan di Lao Hoe terdiri dari suwiran daging ayam yang halus dengan tambahan bihun yang sudah direbus hingga lembut. Kunci kelezatan Laksa Lao Hoe adalah dari campuran beberapa bumbu dapur, kunyit, bawang merah, kemiri, salam, sereh dan lengkuas. Laksa pada umumnya ditebari dengan Ebi, namun di Lao Hoe Ebi tidak digunakan pada tambahan makanan tersebut.

\section{Karakteristik Pedagang Restoran}

1. Umur

Responden dalam penelitian ini adalah pedagang atau pemilik restoran/kedai dengan umur yang dikelompokkan dalam 4 katagori yaitu :(1) 0-14 belum produktif; (2) Produktif 15-65 tahun; dan (4) Tidak produktif lebih dari 65 tahun. Data umur pedagang restoran dapat dilihat dalam Tabel 1.

Tabel 1. Katagori umur pedagang restoran

\begin{tabular}{clcc}
\hline No. & \multicolumn{1}{c}{$\begin{array}{c}\text { Kategori Umur } \\
\text { (tahun) }\end{array}$} & Jumlah Pengrajin Tempe & \% \\
\hline 1. & Belum produktif $(0-14)$ & 0 & 0 \\
2. & Produktif $(15-65)$ & 5 & 83.33 \\
3. & Tidak produktif $>65$ & 1 & 1.67 \\
& & & 0 \\
& & $\mathbf{6}$ & $\mathbf{1 0 0}$ \\
\hline
\end{tabular}


Tabel 1 menunjukkan bahwa dari6 (enam) pedagang restoran yang banyak dikunjungi dan diasumsikan halal paling banyak berada dikatagori produktif yaitu 15-65 tahun sebanyak $83.3 \%$, dan sisanya yaitu 1 orang $(1.67 \%)$ termasuk katagori tidak produktif yaitu berumur $>65$ tahun.Pengkatagorian ketiga umur tersebut sesuai dengan pengkatagorian umur BPS (2016). Dengan demikian pedagang restoran paling banyak berada di usia produktif. Di mana usia produktif adalah orang-orang yang masih dapat bekerja dengan baik menghasilkan barang dan jasa, Ciri-ciri kelompok penduduk usia produktif, yaitu masih sanggup dan energik untuk bekerja, masih bisa berkarya, pekerja keras dan bekerja dengan cerdas, memiliki pandangan dan rencana hidup ke depannya dan mandiri. Dengan banyaknya usia produktif pedagang makapotensi untuk dilakukan sertifikasi halal dapat dilakukan.

2. Jenis Kelamin

Jenis kelamin pedagang restoran terdiri dari laki-laki dan perempuan. Data jenis kelamin pedagang restoran dapat dilihat pada Tabel 2.

Tabel 2. Data jenis kelamin pedagang restoran

\begin{tabular}{cccc}
\hline No. & Jenis kelamin & Jumlah Pengrajin Tempe & \% \\
\hline 1. & Laki-laki & 2 & 33 \\
2. & Perempuan & 4 & 67 \\
& & $\mathbf{6}$ & $\mathbf{1 0 0}$ \\
\hline
\end{tabular}

Tabel 2 menunjukkan bahwa jenis kelamin pedagang restoran paling banyak adalah perempuan (67\%) selebihnya adalah laki-laki (33\%).

3. Agama pedagang restoran

Agama 5 (lima) pedagang restoran dalam penelitian ini terdiri dari agama Kristen dan Budha. Data agama pedagang restoran dapat dilihat pada Tabel 3.

Tabel 3. Agama 5 (lima) pedagang restoran

\begin{tabular}{ccccc}
\hline No. & & Agama & Rupiah & \% \\
\hline 1. & Kristen & 2 & 40 \\
2. & Budha & 3 & 60 \\
& & $\mathbf{5}$ & $\mathbf{1 0 0}$ \\
\hline
\end{tabular}

Tabel 3 menunjukkan bahwa agama 5 (lima) pedagang restoranadalah Kristen 2 (dua) orang (40\%) dan Budha 3 (tiga) orang (60\%). Dari ke 5 (lima) pedagang restoran tidak ada yang beraga islam. 
4. Jumlah pelayan di restoran

Jumlah pelayan di restoran menunjukkan besar/kecilnya aktifitas di restoran. Semakin banyak pelayanan restoran di suatu restoran maka semakin banyak aktifitas yang harus dikerjakan di restoran. Jumlah pelayan di restoran dapat dilihat pada Tabel 4.

Tabel 4. Jumlah pelayan di restoran

\begin{tabular}{clcc}
\hline No. & Restoran/Kedai & Jumlah Pelayan & \% \\
\hline 1. & Pantjoran Tea House & 15 & 47 \\
2. & Gado-Gado Direksi & 5 & 15.6 \\
3. & Es Kopi Tak Kie & 5 & 15.6 \\
4. & Kari Lam Ayam & 2 & 6.2 \\
5. & Mie Kangkung & 1 & 3.1 \\
6. & Laksa Lao Hoe & 4 & 12.5 \\
& & $\mathbf{3 2}$ & $\mathbf{1 0 0}$ \\
\hline
\end{tabular}

Tabel 4 menunjukkan bahwa jumlah pelayan di 6 (enam) restoran berkisar antara 1 sampai 15 orang.Paling banyak terdapat di Pantjoran Tea House, yaitu sebanyak 15 orang sedangkan paling sedikit adalah di mie 121angkong yaitu sebanyak 1 (satu) orang. Hal ini menunjukkan bahwa Pantjoran Tea House memiliki banyak aktifitas dan pelanggan.

\section{Perilaku Halal Pedagang}

Perilaku halal pedagang restoran dilihat dari pengetahuan, sikap dan perilaku penyediaan makanan dan minuman halal. Pengetahuan, sikap dan perilaku halal pedagang restoran. Nilai rata-rata pengetahuan, sikap dan perilaku halal pedagang restorandapat dilihat pada Tabel 5.

Tabel 5. Nilai rata-rata pengetahuan, sikap dan perilaku halal pedagang restoran

\begin{tabular}{llccc}
\hline No. & $\begin{array}{c}\text { Pengetahuan, sikap } \\
\text { dan perilakuhalal }\end{array}$ & $\begin{array}{c}\text { Nilai } \\
\text { Minimun } \\
(\boldsymbol{\%})\end{array}$ & $\begin{array}{c}\text { Nilai } \\
\text { Maksimum } \\
(\boldsymbol{\%})\end{array}$ & $\begin{array}{l}\text { Nilai Rata-Rata(\%) } \pm \\
\text { SD }\end{array}$ \\
\hline 1. & Pengetahuan & 25.00 & 75.00 & $29.17 \pm 20.41$ \\
2. & Sikap & 25.00 & 75.00 & $62.50 \pm 26.22$ \\
3. & Perilaku & 33.33 & 66.67 & $47.20 \pm 12.54$ \\
& Nilai rata-rata & $\mathbf{2 7 . 6 7}$ & $\mathbf{7 2 . 3 3}$ & $\mathbf{4 4 . 9 0 \pm 1 9 . 5 9}$ \\
\hline
\end{tabular}

Tabel 5 menunjukkan bahwa nilai rata-rata pengetahuan halal pedagang adalah 29.17 dengan nilai terendah 25 dan nilai tertinggi 75. Rata-rata nilai sikap halal pedagang adalah 58.33 dengan nilai terendah 25 dan nilai tertinggi 75. Rata-rata nilai perilaku halal pedagang restoran adalah 47.20 dengan nilai terendah 33.33 dan nilai tertinggi 66.67. Secara keseluruhan data menunjukkan bahwa walaupun rata-rata nilai pengetahuan rendah (29.17) pada perilaku juga cenderung rendah (47.2). Secara keseluruhan data juga 
menunjukkan bahwa walaupun rata-rata nilai sikap sedang (62.5), tetapi pada nilai ratarata perilaku halal masih cenderung kurang (47.2). Hal ini menunjukkan sikap halal yang baik belum tentu membuat perilaku halal pedagang baik juga.

Pada pertanyaan pengetahuan diantaranya makanan yang mengandung lemak babi tetap haram walaupun sedikit.Sementara terdapat jawaban terindikasi bisa terjadi pada bumbu yang diracik sendiri pada perilaku halal pedagang. Bisa tercampurnya bahan haram tersebut pada bumbu yang diracik walaupun jumlahnya sedikit,menduduki resiko ke-5 (lima) dari 27 resiko makanan halal di restoran (Sholichah et al., 2017). Hasil rincian ditribusi nilai rata-rata pengetahuan, sikap dan perilaku halal selengkapnya tercantum dalam Tabel 6.

Tabel 6. Distribusi nilai rata-rata pengetahuan, sikap, dan perilaku halal

\begin{tabular}{|c|c|c|c|c|c|c|}
\hline \multirow{3}{*}{$\begin{array}{c}\text { Pengetahuan, sikap dan } \\
\text { Perilakuhalal }\end{array}$} & \multicolumn{6}{|c|}{ Kategori } \\
\hline & \multicolumn{2}{|c|}{ Kurang } & \multicolumn{2}{|c|}{ Sedang } & \multicolumn{2}{|c|}{ Baik } \\
\hline & $\mathbf{N}$ & $\%$ & $\mathbf{N}$ & $\%$ & $\mathbf{N}$ & $\%$ \\
\hline & 5 & 83.33 & 1 & 16.67 & & 0.00 \\
\hline Pengetahuan & 3 & 50.00 & 0 & 0.00 & 3 & 50.00 \\
\hline $\begin{array}{l}\text { Sikap } \\
\text { Perilaku }\end{array}$ & 5 & 83.33 & 1 & 16.67 & 0 & 0.00 \\
\hline Rata-rata & 4.3 & 72.22 & 0.67 & 11.11 & 1 & 16.67 \\
\hline
\end{tabular}

Tabel 6 menunjukkan bahwa berdasarkan nilai rata-rata, nilai yang diperoleh dikategorikan baik dengan nilai $>80 \%$, sedang $60 \%-80 \%$ dan kurang $<60 \%$, maka pengetahuanhalal masing-masing pedagang dikategorikan kurangsebanyak $83.33 \%$, sikap halal pedagang dikatagorikan kurang dan baik, masing-masing sebanyak 50\%.Perilaku halal dikategorikan kurang sebesar 83.33\%. Dengan demikian, secara keseluruhan distribusi nilai rata-ratapengetahuan, sikap, dan perilaku halal dikatagorikan kurang (72.22\%), walaupun demikian dari 6 (enam) orang pedagang hanya 1 (satu) orang pedagang yang tidak bersedia bila dilakukan sertifikasi halal tanpa biaya. Sehingga 83.3\% pedagang berminat disertifikasi halal MUI tanpa biaya. Dapat juga dikatakan dari pihak pedagang restoran favorit dengan asumsi halal (supplier), wilayah pecinan petak 9 memiliki potensi untuk dikembangkan menjadi wisata gastronomi halal.

\section{Pendapat Pakar}

Pendapat pakar menyatakan bahwa perkembangan wisata halal di suatu kawasan kuliner masih sangat jarang. Riset yang dilakukan oleh halal watch menunjukkan bahwa 3.081 restoran di Indonesia hanya $1.56 \%$ atau 48 restoran yang telah memiliki sertifikasi halal dari MUI (Suryana, 2017). Walaupun pertumbuhan restoran menengah ke atas tinggi yaitu hingga 250\% dalam lima tahun terakhir (Asdhiana, 2014), tetapi banyak restoran yang belum banyak bersertifikat halal, tapi baru pada tataran self claim (Andrana, et al., 2015). Di Indonesia walaupun wisata halal pada restoran atau makanan sangat diperlukan untuk wisatawan muslim. Sertifikasi halal bagi restoran atau bagi makanan minuman sebagai informasi bagi wisatawan yang ingin menikmati gastronomi. 
Bagi kawasan di wilayah Pecinan seperti petak 9, Glodok sertifikasi halal mempunyai peluang besar dilakukan untuk menarik minat wisatawan muslim baik lokal maupun internasional. Pakar menyatakan bahwa pentingnya informasi halal bersertifikasi MUI pada restoran di wilayah Pecinan Petak 9, Glodok, Jakarta. Dapat disimpulkan bahwa kawasan kuliner di Petak 9 Glodok Jakarta memiliki potensi sebagai wisata gastronomi halal.

\section{KESIMPULAN}

Kesimpulan dari penelitian ini adalah :

1. Restoran tempo dulu yang menjadi favorit dengan asumsi halal sebanyak 6 (enam) buah;

2. Distribusi nilai rata-rata pengetahuan, sikap, dan perilaku halal dikatagorikan kurang (72.22\%), walaupun $83.3 \%$ pedagang berminat disertifikasi halal MUI tanpa biaya;

3. Pakar menyatakan bahwa pentingnya informasi halal bersertifikasi MUI pada restoran di wilayah Pecinan Petak 9, Glodok, Jakarta.

\section{UCAPAN TERIMA KASIH}

Terima kasih diucapkan kepada LPPM Universitas Sahid Jakarta yang telah memberi dukungan financial pada penelitian ini.

\section{DAFTAR PUSTAKA}

Alamsyah, AN. (2018). Kesiapan Objek Wisata Menuju Wisata Syariah Di Kawasan Hutan Lindung Mangunan Daerah Istimewa Yogyakarta. Universitas Islam Indonesia. Yogyakarta

Andriani, D. Akbar, K. Aqmarina, L. Nurhayati, Permanasari T., Binarwan IK, R. Murniati, D. (2015). Laporan Akhir Kajian Pengembangan Wisata Syariah. Asisten Deputi Penelitian dan Pengembangan Kebijakan Kepariwisataan Deputi Bidang Pengembangan Kelembagaan Kepariwisataan Kementerian Pariwisata.

Asdhiana, IM. (2014). Makan di Restoran Semakin Ngetren. http://travel.kompas.com/read/2014/04/04/1632122/Makan.di.Restoran.Semakin. Ngetren. Diakses pada 14 April 2017.

$\begin{array}{llll}\text { Badan Pusat } & \text { Statistik (BPS). } & \text { (2016). }\end{array}$ https://www.bps.go.id/istilah/index.html?Istilah\%5Bberawalan\%5D=A\&Istilah_p $\underline{\text { age }=3}$ Diakses pada 27 November 2018.

Murti C. (2016). Pengaruh Pengetahuan dan Kesadaran terhadap Perilaku Pembelian Pangan Halal. Skripsi. Bogor. Fakultas Ekologi Manusia. Institut Pertanian Bogor. Bogor. 
Rachmadewi, A. \& Khomsan A. (2009). Pengetahuan, Sikap dan Praktek ASI Eksklusif serta Status Gizi Bayi Usia 4-12 bulan di Pedesaan dan di Perkotaan. Jurnal Gizi dan Pangan. 4(2): 83-90.

Sholichah, W.Vanany, I. Soeprijanto, A. Anwar, MK., \& Fatmawati, L. (2017). Analisis Risiko Makanan Halal Di Restoran Menggunakan Metode Failure Mode and Effect Analysis. Jurnal Ilmiah Teknik Industri 16(1) : 150-156.

Suryana, W. (2017). Baru 48 Restoran di Indonesia yang Bersertifikat Halal. https://republika.co.id/berita/ekonomi/syariah-ekonomi/17/06/30/oscz2j330-baru48-restoran-di-indonesia-yang-bersertifikat-halal. Diakses tanggal 26 November 2018.

Waskito, D. (2015). Pengaruh Sertifikasi Halal, Kesadaran Halal dan Bahan Makanan terhadap Minat Beli Produk Makanan Halal (Studi pada Mahasiswa Muslim di Jogjakarta). Skripsi. Fakultas Ekonomi. Universitas Negeri Yogjakarta. Yogjakarta.

Yusof, SM. \& Shutto N. (2014). The Development of Halal Food Market in Japan : An Exploratory Study. Procedia-Social and Behavioral Sciences 121 : 253-261. 